\title{
PERLINDUNGAN HAK TERKAIT SEHUBUNGAN DENGAN COVER VERSION LAGU BERDASARKAN UNDANG-UNDANG HAK CIPTA
}

\author{
Oleh \\ I Gusti Putu Agung Angga Aditya \\ Anak Agung Ketut Sukranatha, SH., MH. \\ Bagian Hukum Bisnis Fakultas Hukum Universitas Udayana
}

\begin{abstract}
ABSTRAK
Kebebasan berekspresi yang tidak terbatas telah menimbulkan fenomena baru dalam dunia musik yang disebut cover version pada lagu. Pencipta atau pemegang Hak Cipta memiliki hak eksklusif terhadap suatu lagu ciptaan. Oleh karena itu, jika terdapat pihakpihak yang ingin mengkomersialisasikan lagunya dengan membuat cover version, pihak tersebut harus memperoleh izin terlebih dahulu dari pencipta atau pemegang Hak Cipta. Penelitian ini menggunakan metode penelitian hukum normatif, dengan jenis pendekatan yang digunakan yaitu pendekatan perundang-undangan dan pendekatan analisis bahan hukum. Berdasarkan hasil penelitian dapat disimpulkan bahwa cover version lagu didalam Undang-Undang Nomor 28 Tahun 2014 tidak diatur secara eksplisit namun secara impisit dalam Pasal 9 huruf $b$ dan d dan cover version mendapat perlindungan hukum hak cipta namun termasuk sebagai pelanggaran jika Cover Version lagu dilakukan tanpa izin pencipta lagu dan bertujuan untuk dikomersialkan. Saran dari penelitian ini yaitu dalam rangka menjamin kepastian hukum, haruslah dibentuk undang-undang untuk menyempurnakan ketentuan mengenai peraturan yang mengatur cover version secara jelas sehingga tidak menghambat para musisi-musisi untuk berkarya.
\end{abstract}

\section{Kata Kunci: Perlindungan Hukum, Hak Cipta, Cover Version}

\author{
ABSTRACT \\ Unlimited freedom of expression has created a new \\ phenomenon in the world of music called cover version on songs. The \\ creator or copyright holder has exclusive rights to a song of creation. \\ Therefore, if there are parties who want to commercialize the song by
}


making a cover version, the party must obtain prior permission from the creator or copyright holder. This study uses legal materials, with the type of approach used, namely the legislation approach, case approach and legal material analysis. Based on the results of the study it can be concluded that the cover version of the song in Law No. 28 of 2014 is not explicitly regulated but implicitly in Article 9 letters $\mathrm{b}$ and $\mathrm{d}$ and cover version get copyright law protection but include violations if the Cover Version song is done without permission songwriter and aims to be commercialized. The suggestion from this research is that in order to guarantee legal certainty, a law must be established to improve the provisions regarding the rules that clearly regulate the cover version so as not to inhibit the musicians to work.

\section{Keywords: Legal Protection, Copyright, Cover Version}

\section{PENDAhUluan}

\subsection{Latar Belakang}

Karya cipta yang bersumber dari hasil kreasi akal dan budi manusia dalam perkembangannya telah melahirkan suatu hak yang disebut dengan Hak Cipta. Hak Cipta tersebut melekat pada diri seseorang pencipta atau pemegang Hak Cipta, sehingga lahirlah dari Hak Cipta tersebut hak ekonomi (economic rights) dan hak moral (moral rights). Dalam usaha untuk mengekploitasi karya cipta musik, pencipta, pelaku dan produser rekaman suara yang ciptaanya, pertunjukan ataupun rekaman suaranya dapat mengunggah ciptaan ke internet untuk dipublikasikan dan diperoleh manfaat ekonominya. 
Hal tersebut dalam satu sisi memiliki dampak positif yaitu masyarakat luas dapat mengakses karya tersebut dan menikmatinya, Meskipun begitu, disisi lain dampak negatif yang dapat muncul adalah penikmat-penikmat lagu tersebut mengumumkan kembali kepada publik suatu lagu yang telah diubah sedemikian rupa oleh mereka menjadi suatu karya yang baru. Hal ini yang dimaksud dengan kegiatan memproduksi cover version dari suatu lagu. Cover sendiri dipahami sebagai versi kedua, dan seluruh versi sesudahnya, dari sebuah lagu yang dipertunjukan selain oleh pihak yang secara orisinil merekamnya atau siapapun terkecuali penulis lagu.

Kebebasan berekspresi seakan-akan berada pada satu titik dimana keberadaanya telah mengusik Hak Cipta, meskipun terdapat pendapat bahwa Hak Cipta dan kebebasan berkespresi dapat menyatu karena perlindungan Hak Cipta hanya mencakup kepada "ekspresi" pencipta, dan bukan kepada "ide" atau informasi yang didapat dari suatu ciptaan. Hal ini berdampak kepada pencipta maupun pelaku lain memiliki kebebasan untuk mengekspresikan ide yang sama atau menggunakan kembali informasi yang diperoleh dari ciptaan atau karya yang dilindungi kedalam karya sesudahnya selama pencipta maupun pelaku tersebut mengekspresikan ide atau informasi tersebut dalam cara berbeda. 
Kemajuan teknologi membawa pengaruh baik positif maupun negatif terhadap perkembangan Hak Cipta dalam bidang lagu, hal-hal positif yang berkaitan dengan itu adalah peredaran lagu menjadi cepat dari suatu tempat ke tempat yang lain sehingga penyanyi menjadi lebih terkenal namun ada juga dampak negatifnya, yaitu tidak hanya penciptanya atau penyanyi aslinya yang menggandakan dan mengumumkan lagu itu tetapi mulai banyak pihak-pihak lain dengan tanpa ijin melakukan cover lagu, sesungguhnya fenomena cover lagu tidak hanya merugikan penciptanya tetapi juga penyanyi aslinya dan produser yang dalam Undang-undang Hak Cipta Pasal 1 huruf 5 UU Nomor 28 Tahun 2014 tentang Hak Cipta termasuk dalam Hak Terkait. Sehubungan dengan itu maka penting untuk ditulis sebuah karya ilmiah yang berjudul "Perlindungan Hak Terkait Sehubungan Dengan Cover Version Lagu Berdasarkan UndangUndang Hak Cipta"

\subsection{Tujuan Penelitian}

Tujuan dalam penulisan ini adalah untuk mengetahui bagaimana perlindungan hukum bagi penyayi asli dan produser sebagai pemegang hak terkait berkaitan dengan cover version lagu dan penyelesaian sengketa berkaitan dengan pelanggaran hak terkait dalam konteks cover version. 


\section{ISI MAKALAH}

\subsection{Metode Penelitian}

Metode penelitian yang digunakan yaitu penelitian hukum normatif dengan menggunakan pendekatan perundang-undangan. Menggunakan bahan hukum yang bersumber dari norma atau kaidah dasar, peraturan perundang-undangan, kebijakan, dan publikasi yang dibuat oleh pemerintah, buku-buku literatur dan bahan lainnya yang tentunya berhubungan dengan masalah yang sedang diteliti. Bahan hukum sekunder meliputi buku-buku, literatur, makalah, tesis, skripsi, dan bahan-bahan hukum tertulis lainnya yang berhubungan dengan permasalahan penelitian.

\subsection{Hasil dan Pembahasan}

\subsubsection{BAGAIMANA PERLINDUNGAN HUKUM BAGI PENYANYI ASLI DAN PRODUSER SEBAGAI PEMEGANG HAK TERKAIT BERKAITAN DENGAN COVER VERSION LAGU}

Cover Version merupakan kegiatan membawakan ulang sebuah lagu yang sebelumnya pernah direkam dan dinyanyikan oleh seorang musisi. Saat ini banyak lagu cover version yang lebih terkenal dibandingkan lagu yang dibawakan penyanyi asli. Hal terssebutlah 
yang mendorong musisi-musisi baru yang mengikuti dalam membawakan lagu cover version agar lebih cepat terkenal. ${ }^{1}$

Unsur-unsur dalam cover version yaitu sebagai berikut:

1. Hasil rekaman baru

2. Membawakan ulang sebuah lagu yang dibawakan penyayi lain

3. Menambahkan kontribusi kreatif tertentu seperti misalnya menambah irama atau aransemen

4. Mengatur ulang notasi musik

5. Menuliskan dan menerjemahkan kembali suatu musik kedalam gaya musik lain yang berbeda

Para seniman musik, baik sebagai pencipta, maupun penyayi mungkin saja mendapat tempat yang terhomat di masyarakat dan mendapat penghargaan baik secara moral maupun ekonomis. Meskipun demikian, tidak ada bukti autentik bahwa hak-hak pencipta lagu atau musik, pemusik, dan penyayi telah mendapat perlindungan hukum sejak dahulu kala.

Dalam Undang-Undang Hak Cipta sendiri mendefinisakan Penggandaan adalah proses, perbuatan, atau cara menggandakan

\footnotetext{
${ }^{1}$ Lucky Setiawan, 2014, “Apakah Menyayikan Lagu Oranglain Melanggar Hak Cipta” URL:http://hukumonline.com/apakah-menyayikan-ulang-lagu-orang-lain-melanggar-hak-cipta, diakses 9 Agustus 2018.
} 
satu salinan Ciptaan dan/atau fonogram atau lebih dengan cara dan dalam bentuk apapun, secara permanen atau sementara, sedangkan definisi dari Pengalihwujudan adalah pengubah bentuk, misalnya dari bentuk patung menjadi lukisan dan novel menjadi film. Mengubah karya musik dari format CD (compact disc) menjadi MP3 (MPEGI player 3), Winamp dan Windows Media Player yang memberikan peluang pelanggaran hak cipta atas karya musik (pembajakan) menjadi lebih mudah dan dengan kualitas yang sama baiknya dengan karya musik aslinya. ${ }^{2}$

Pihak-Pihak yang dirugikan dalam fenomena cover version tersebut bukan hanya dari pencipta melainkan penyanyi/ group band yang menyanyikan lagu itu dan juga produser sebagi pihak yang memproduksi lagu. Perlindungan Hukum bagi penyanyi asli dan produser sebagai pihak yang memproduksi lagu dinyatakan dalam Pasal 1 huruf 5 Undang-Undang Nomor 28 Tahun 2014 tentang Hak Cipta yang menyatakan "Hak Terkait adalah hak yang berkaitan dengan Hak Cipta yang merupakan hak eksklusif bagi pelaku pertunjukan, producer fonogram, atau lembaga penyiaran"

${ }^{2}$ Ibid. 


\subsubsection{PENYELESAIAN SENGKETA BERKAITAN DENGAN PELANGGARAN HAK TERKAIT DALAM KONTEKS COVER VERSION}

Pengegakan hukum hak cipta yang dimaksud tidak lain untuk mewujudkan cita-cita hukum yang terkandung dalam UndangUndang Nomor 28 Tahun 2014 tentang Hak Cipta. Apabila tujuan itu tidak terlaksana, maka akan ada pihak-pihak tertentu yang mendapatkan kerugian, berupa kerugian ekonomi yang terjadi akibat adanya pelanggaran hukum hak cipta.

Berdasarkan Pasal 8 UU Hak Cipta hak ekonomi merupakan hak eksklusif Pencipta atau pemegang Hak Cipta untuk mendapatkan manfaat ekonomi atas Ciptaan. Dalam bidang hak ekonomi tidak semua karya kreativitas mendapat perlindungan Hak Ekonomi (Economic Rights). Hak tersebut hanya diberikan kepada seseorang yang benar-benar berhasil melahirkan kreativitas yang orisinil di bidang Hak Cipta, sementara itu di bidang Paten, hak eksklusif hanya diberikan terhadap penemuan yang baru, tidak terpikirkan dan sangat berguna (mengandung langkah inventif), serta dapat diterapkan dalam kegiatan industri. ${ }^{3}$ Suatu ciptaan merupakan hasil karya yang dilihat dari aspek ekonomi pengorbanan merupakan

\footnotetext{
${ }^{3}$ Ni Ketut Supasti Dharmawan, 2011, Hak Kekayaan Intelektual dan Harmonisasi Hukum Global, Rekontruksi Pemikiran Terhadap Perlindungan Program Komputer, Badan Penerbit Universitaas Diponogoro, Semarang, hlm.49.
} 
suatu investasi yang perlu dikelola secara komersial untuk mendapatkan pengembalian modal memperoleh keuntungan. Semakin bermutu suatu ciptaan semakin tinggi pula potensi nilai komersialnya diperbolehkan. ${ }^{4}$

Jadi Hak ekonomi tersebut merupakan hak untuk memperoleh keuntungan ekonomi atas kekayaan intelektual karena Hak Kekayaan Intelektual adalah benda yang dapat dinilai dengan uang. Hak ekonomi tersebut berupa keuntungan sejumlah uang yang diperoleh karena penggunankan sendiri Hak Kekayaan Intelektual atau penggunaan oleh orang lain berdasarkan lisensi. Hak ekonomi tersebut diperhitungkan karena Hak Kekayaan Intelektual dapat digunakan oleh orang lain dalam penindustrian atau perdagangan yang mendatangkan keuntungan.

Pencipta dan pemegang Hak Cipta sebagaimana dimaksud Pasal 8 Undang-Undang Nomor 28 Tahun 2014 tentang Hak Cipta memiliki hak ekonomi untuk melakukan:

a. Penerbitan Ciptaan;

b. Penggandaan Ciptaan dalam segala bentuknya

c. Penerjemah Ciptaan

\footnotetext{
${ }^{4}$ Yahya Ahmad zein, 2012, Problematika Hak Asasi Manusia (HAM), Yogyakarta, Liberty, $h$.
} 46. 
d. Pengadaptasian, pengaransemenan, atau pentransformasian ciptaan

e. Pendistribusian ciptaan atau salinannya

f. Pertunjukan Ciptaan

g. Pengumuman ciptaan

h. Komunikasi ciptaan

i. Penyewaan ciptaan.

Jadi setiap orang yang melaksanaakan hak ekonomi wajib mendapatkan izin pencipta atau pemegang hak cipta. Setiap orang yang tanpa izin pencipta atau pemegang hak cipta. Setiap orang yang tanpa izin pencipta atau pemegang hak cipta dilarang melakukan penggandaan atau penggunaan secara komersial ciptaan.

Sesuai dengan penjelasan pasal diatas maka dapat diketahui yang bisa disebut suatu pelanggaran terhadap sebuah karya ciptaan apabila:

1. Terjadi pengekspoitasian (pengumuman, penggandaan dan pengedaran) untuk kepentingan komersial sebuah karya cipta tanpa terlebih dahulu meminta izin atau mendapatkan lisensi dari penciptanya atau ahli warisnya. Termasuk didalamnya tindakan penjiplakan. 
2. Peniadaan nama pencipta pada ciptaanya.

3. Penggantian atau perubahan nama pencipta pada ciptaanya yang dilakukan tanpa persetujuan dari pemilik hak ciptanya.

4. Penggantian atau perubahan judul sebuah ciptaan tanpa persetujuan dari penciptanya atau ahli warisnya.

Dalam hal tersebut cover version termasuk melanggar point 1 yakni perbuatan penggandaan dengan pembuatan karya musik atau lagu yang sama, hampir sama, atau menyerupai sebuah karya musik atau lagu penyanyi aslinya untuk kepentingan komersil sehingga termasuk pelanggaran hak moral dan hak ekonomi.

Lagu atau musik dapat memberikan keuntungan yang besar dari segi ekonomi karena manusia cenderung ingin meniru dan menguasai ciptaan orang lain yang dapat merugikan pemegang hak terkait sesuai Pasal 1 huruf 5 Undang-Undang Nomor 28 Tahun 2014 tentang Hak Cipta yang menyatakan "Hak Terkait adalah hak yang berkaitan dengan Hak Cipta yang merupakan hak eksklusif bagi pelaku pertunjukan, producer fonogram, atau lembaga penyiaran”. Pencipta dan pemegang hak terkait tersebut dapat melakukan upaya untuk menyelesaikan sengketa dan mencegah pelanggaran hak cipta dengan upaya preventif dan juga upaya pada saat suatu pelanggaran hak cipta terjadi atau upaya represif dan menurut Pasal 95 Undang- 
Undang Nomor 28 Tahun 2014 tentang Hak Cipta mengatur mengenai penyelesaian sengketa hak cipta di Indonesia dapat dilakukan melalui alternatif penyelesaian sengketa, arbitrase atau pengadilan.

\section{KESIMPULAN}

Berdasarkan hasil penelitian yang telah diuraikan, maka dapat disimpulkan bahwa:

3.1 Cover Version lagu dalam Undang-Undang Nomor 28 Tahun 2014 tidak diatur secara eksplisit, namun secara implisit termasuk kedalam pengertian penggandaan dan aransemen sebagaimana diatur dalam Pasal 9 huruf $b$ dan $d$.

3.2 Cover Version mendapatkan perlindungan hukum hak cipta, namun termasuk sebagai pelanggaran jika Cover Version lagu dilakukan tanpa izin pencipta lagu dan bertujuan untuk dikomersialkan.

\section{DAFTAR PUSTAKA}

Lucky Setiawan, 2014, "Apakah Menyayikan Lagu Oranglain Melanggar Hak Cipta" URL:http://hukumonline.com/apakah- 
menyayikan-ulang-lagu-orang-lain-melanggar-hak-cipta, diakses 9 Agustus 2018.

Zein, Yahya Ahmad, 2012, Problematika Hak Asasi Manusia (HAM), Yogyakarta, Liberty.

Otto Hasibuan 2008, Hak Cipta di Indonesia, PT. Alumni, Bandung.

Ni Ketut Supasti et. al., 2017, Hak Kekayaan Intelektual, Deepublish, Yogyakarta. 